\title{
PERILAKU DEFORMASI BENDUNGAN JATIBARANG
}

\author{
Fajar Aldoko Kurniawan ${ }^{1)}$, S.P.R Wardani ${ }^{2)}$, Kresno Wikan Sadono ${ }^{3)}$ \\ ${ }^{1)}$ BBWS Pemali Juana, Kementerian Pekerjaan Umum dan Perumahan Rakyat \\ ${ }^{2,3)}$ Program Studi Magister Teknik Sipil, Fakultas Teknik, Universitas Diponegoro \\ Email: fajaraldokokurniawan@gmail.com ${ }^{1)}$,wardani_spr@yahoo.com ${ }^{2)}$, \\ kresnowikansadono@lecturer.undip.ac.id ${ }^{3)}$
}

DOI: http://dx.doi.org/10.29103/tj.v11i2.592

(Received: July 2021 / Revised: August 2021 / Accepted: September 2021)

\begin{abstract}
Abstrak
Efek utama dari deformasi adalah hilangnya freeboard, kerusakan struktur bangunan pelengkap yang terletak di atas bendungan, retakan pada bendungan urugan (paling merugikan pada impervious core), terbentuknya suatu zona yang mengarah pada hidrolik fracturing, dan kegagalan instrumentasi. Bendungan Jatibarang merupakan bendungan urugan batu zonal inti tegak dengan inti clay. Tujuan dari penelitian ini adalah untuk menganalisis perilaku deformasi pada berbagai tahapan saat konstruksi, selama pengisian awal waduk dan pasca konstruksi (masa layan). Penelitian ini dilakukan dengan menggunakan data pembacaan instrumen pengukur deformasi dan evaluasi menggunakan kriteria penerimaan untuk menilai perilaku normal dan tidak normal. Hasil dari penelitian ini adalah selama konstruksi, deformasi vertikal Bendungan Jatibarang pada kedalaman antara $32 \mathrm{~m}$ sampai kedalaman $56 \mathrm{~m}$ berada di luar batas deformasi normal. Pergerakan deformasi horizontal pada pengisian awal dari Bendungan Jatibarang mempunyai nilai deformasi yang besar karena berada di atas perilaku umum deformasi horizontal pada beberapa bendungan. Pada kurun waktu konstruksi Bendungan Jatibarang 2014 hingga pembacaan terakhir pada tahun 2020 terlihat tidak terjadi perubahan yang signifikan namun pada kedalaman antara $20-30 \mathrm{~m}$ terjadi penurunan yang besar dibandingkan dengan lainnya yang mengindikasikan bahwa pada kedalaman tersebut terjadi konsentrasi penurunan internal yang besar
\end{abstract}

Kata kunci: Bendungan Jatibarang, instrumentasi, deformasi, deformasi vertikal, deformasi horizontal

\begin{abstract}
The main effects of deformation are loss of freeboard, damage to the auxiliary structure located above the dam, cracks in the embankment dam (impervious core), formation of a zone leading to hydraulic fracturing, and instrumentation failure. Jatibarang Dam is an upright core zonal rockfill dam with a clay core. The purpose of this study is to analyze the deformation behavior at various stages during construction, during the initial filling of the reservoir and post construction (post construction). This research was conducted using the reading data of the deformation instrumen and the evaluation using acceptance criteria to assess normal and abnormal behavior. The result of this research is that during construction, the vertical deformation at a depth between $32 \mathrm{~m}$ to $56 \mathrm{~m}$ is outside the normal deformation limit. The horizontal deformation at the initial filling of the Jatibarang Dam has a large deformation value because it is above the general horizontal deformation behavior of several dams. During the construction period 2014 until 2020 Jatibarang Dam did not appear to be any significant changes, but at a depth between 20-30 meters there was a large decrease compared to others indicating that at depth there was a large concentration of internal decline.
\end{abstract}

Keywords: Jatibarang dam, instrumentation, deformation, vertical deformation, horizontal deformation 


\section{Latar Belakang}

Bendungan urugan batu dapat diklasifikasikan menjadi tiga kelompok, tergantung pada lokasi membran yaitu inti tegak, inti miring, dan membran hulu atau berlapis (Bureau of Reclamation, 2012). Bendungan Jatibarang yang berada di Kota Semarang merupakan bendungan urugan batu zonal inti tegak dengan kapasitas tampungan efektif antara EL. 136,0 m dan EL. 151,8 m dengan volume 13,6 juta $\mathrm{m}^{3}$ (Kementerian Pekerjaan Umum dan Perumahan Rakyat, 2008). Konstruksi Bendungan Jatibarang dimulai pada Oktober 2009 dan selesai pada bulan Mei 2014. Sertifikasi operasional didapatkan pada 11 Mei 2015 dan masih beroperasi hingga sekarang (BBWS Pemali Juana, 2014). Manfaat dari pembangunan Bendungan Jatibarang adalah meningkatkan kelestarian fungsi konservasi DAS Garang, pengendalian banjir dengan mengurangi debit banjir sebesar $170 \mathrm{~m}^{3} /$ detik, sebagai penyedia air baku kota Semarang 1050 liter/detik, potensi PLTMH 1,5 MW, potensi parawisata kota Semarang.

Suatu bangunan apabila mendapatkan tekanan dari luar maupun dari beban bangunan itu sendiri maka akan mengalami suatu perubahan bentuk dan dimensi (deformasi). Berdasarkan pada fungsi bendungan yang menahan laju aliran air maka bendungan akan mendapatkan tekanan akibat efek pembebanan air serta tekanan dari tubuh bendungan itu sendiri sehingga bendungan mempunyai potensi mengalami deformasi. Menurut USBR (2011) efek utama dari deformasi adalah hilangnya freeboard, kerusakan struktur bangunan pelengkap yang terletak di atas bendungan, hilangnya kepercayaan pada bendungan karena swayback (penampakan lendutan), retakan pada bendungan urugan (paling merugikan pada impervious core), terbentuknya suatu zona yang mengarah pada hidrolikfracturing, dan kegagalan instrumentasi.

Fajar Rudi Purwoko (2016) melakukan penelitian pemantauan deformasi Bendungan Jatibarang menggunakan scientific software Gamit 10.6 dengan menghitung nilai-nilai deformasi beserta arah pergerakan dari titik pengamatan yang terdapat pada tubuh utama bendungan dengan cara uji statistik. Penelitian serupa dilakukan oleh M. Adnan Yusuf (2015) menggunakan metode pengukuran deformasi relatif dengan alat ukur GPS dual frequency GAMIT 10.5 pada sembilan titik pengamatan yang berada di Bendungan UNDIP. Rheky Julistian (2020) melakukan analisis kestabilan Bendungan Lolak 1 dengan menggunakan pemodelan Plaxis pada penurunan tiap timbunan yang terjadi pada tubuh bendungan pada zona inti 1, di mana angka maksimum deformasi yang terjadi dari hasil analisis beberapa kondisi yaitu sebesar $0.186 \mathrm{~m}$. Penelitian Rizki Fadillah (2017) melakukan pengamatan deformasi terhadap Waduk Pendidikan Diponegoro, dengan metode pengamatan GPS (Global Positioning System).

Untuk mempertahankan fungsi bendungan dalam kasus deformasi maka diperlukan perawatan dan pemeliharaan serta evaluasi dan monitoring deformasi secara rutin dan berkala. Pergerakan pada suatu titik dalam dam atau fondasi dapat diuraikan menjadi 3 komponen yaitu vertikal, horizontal dan lateral (TADS (Training Aids for Dam Safety), 2011). Tujuan penelitian ini adalah untuk menilai perilaku deformasi pada berbagai tahapan saat konstruksi (during construction), selama pengisian awal waduk (initial filling) dan pasca konstruksi (masa layan). diperlukan untuk memberikan gambaran perilaku bendungan serta memberikan petunjuk pada tiap tahapan. Evaluasi deformasi memberikan gambaran awal terhadap kriteria penerimaan deformasi. Proses evaluasi deformasi dilakukan 
dengan membandingkan besar dan arah kejadian deformasi dengan kriteria penerimaan deformasi sehingga dapat digunakan untuk pengambilan keputusan terkait dengan konstruksi dan pemeliharaan bendungan.

\section{Metode Penelitian}

\subsection{Pengumpulan Data}

Data pembacaan pada instrumen Bendungan Jatibarang yang meliputi data elevasi magnet vertical settlement Probe Extenzometer (PE) dari BBWS Pemali Juana (2020) dengan jumlah magnet plat 15 buah dari tahun 2013 sampai 2020 (Tabel 1). Lokasi instrumen seperti pada Gambar 1 (BBWS Pemali Juana, 2010).

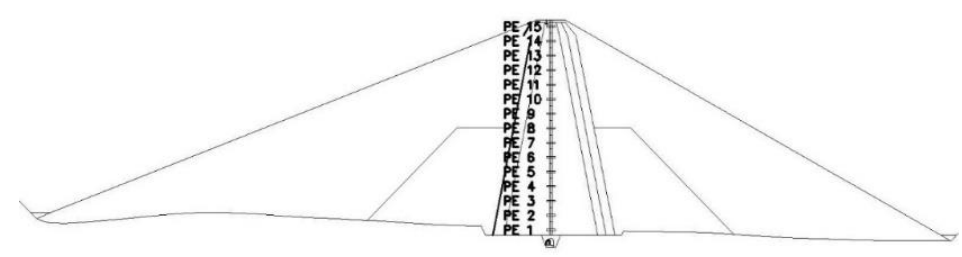

Gambar 1 Lokasi instrumen Probe Extenzometer (PE) bendungan Jatibarang

Tabel 1 Data pembacaan elevasi probe extenzometer

\begin{tabular}{ccccc}
\hline \multirow{2}{*}{ Magnet } & \multicolumn{4}{c}{ Data Reading Elevation (m) } \\
\cline { 2 - 5 } & $\begin{array}{c}\text { Initial } \\
\text { 6 Maret 2013 }\end{array}$ & $\begin{array}{c}\text { End of Construction } \\
\text { 6 Mei 2014 }\end{array}$ & $\begin{array}{c}\text { Initial Filling } \\
\text { 12 Mei 2015 }\end{array}$ & $\begin{array}{c}\text { Post Construction } \\
\text { 23 Juni 2020 }\end{array}$ \\
\hline PE 1 & 83.60 & 83.50 & 83.50 & 83.50 \\
\hline PE 2 & 88.98 & 88.69 & 88.69 & 88.69 \\
\hline PE 3 & 94.37 & 93.89 & 93.88 & 93.88 \\
\hline PE 4 & 98.78 & 98.20 & 98.18 & 98.17 \\
\hline PE 5 & 103.84 & 103.09 & 103.07 & 103.05 \\
\hline PE 6 & 109.09 & 108.17 & 108.15 & 108.13 \\
\hline PE 7 & 113.48 & 112.50 & 112.46 & 112.43 \\
\hline PE 8 & 118.67 & 117.66 & 117.61 & 122.27 \\
\hline PE 9 & 123.45 & 122.36 & 122.32 & 127.36 \\
\hline PE 10 & 128.45 & 127.46 & 127.41 & 132.47 \\
\hline PE 11 & 133.62 & 132.57 & 132.53 & 137.61 \\
\hline PE 12 & 138.50 & 137.71 & 137.65 & 142.76 \\
\hline PE 13 & 143.53 & 142.88 & 142.83 & 153.03 \\
\hline PE 14 & 148.56 & 148.14 & 148.06 & \\
\hline PE 15 & 153.41 & 153.16 & 153.09 & \\
\hline
\end{tabular}

Data yang digunakan dalam menghitung besarnya pergerakan pada permukaan tubuh bendungan menggunakan pembacaan patok geser yang berjumlah 14 buah dari tahun 2014 sampai 2016 (Tabel 2 dan Tabel 3). Untuk mengetahui arah pergerakan deformasi pada pembacaan patok geser maka diperlukan petunjuk arah. Pembacaan pada X (+) menunjukkan pergerakan kearah Timur (abutment kanan) dan pada pembacaan X (-) menunjukkan pergerakan kearah Barat (abutment kiri). Pembacaan pada $\mathrm{Y}(+)$ menunjukkan pergerakan kearah downstream dan pembacaan Y (-) menunjukkan pergerakan kearah upstream (Gambar 3). Pergerakan deformasi horizontal difokuskan pada posisi hilir bendungan di area mid to downstream yaitu pada area $0.6 \mathrm{H}-0.8 \mathrm{H}$ (Gambar 2) dari puncak bendungan kearah hilir. 


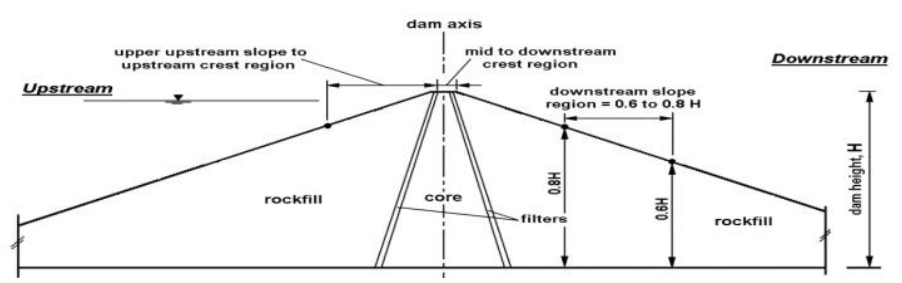

Gambar 2 Zona pengamatan deformasi (Hunter, G., \& Fell, 2003b)

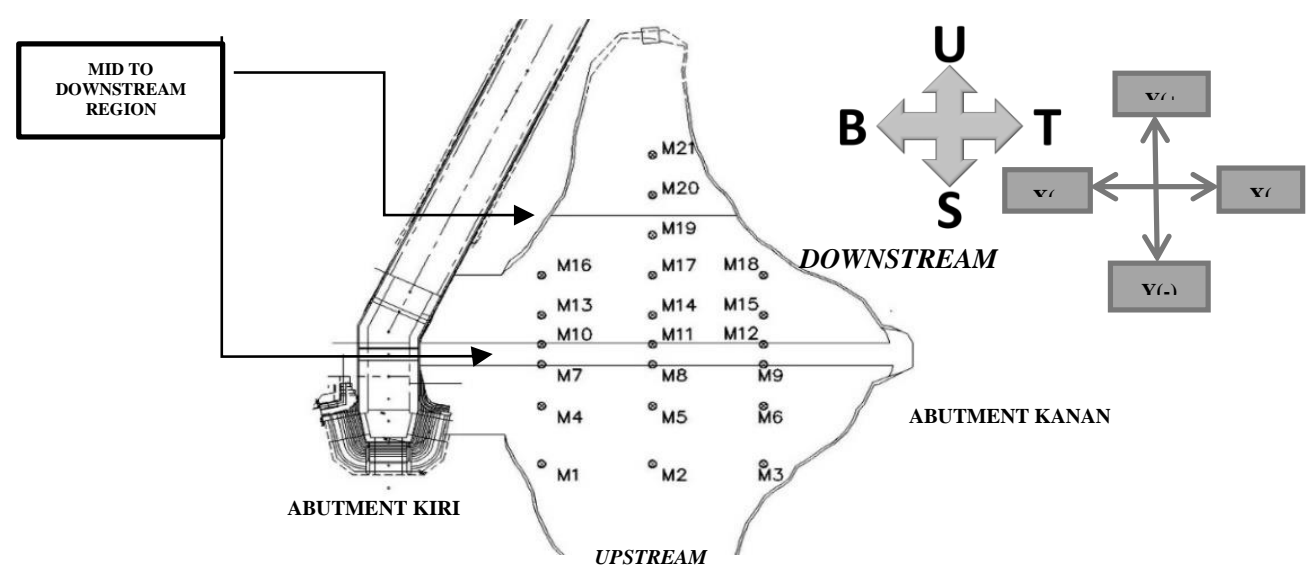

Gambar 3 Petunjuk arah deformasi patok geser Bendungan Jatibarang

Tabel 2 Posisi patok geser kondisi awal pemasangan

\begin{tabular}{cccc}
\hline Patok & X & Y & Z \\
\hline M1 & 428226.17 & 9222193.36 & 140.00 \\
\hline M2 & 428267.58 & 9222175.39 & 139.81 \\
\hline M3 & 428308.80 & 9222157.62 & 140.13 \\
\hline M4 & 428236.56 & 9222217.19 & 150.28 \\
\hline M5 & 428277.78 & 9222199.35 & 150.19 \\
\hline M6 & 428319.11 & 9222181.56 & 150.17 \\
\hline M7 & 428243.91 & 9222234.34 & 157.41 \\
\hline M8 & 428285.20 & 9222216.54 & 157.98 \\
\hline M9 & 428326.52 & 9222198.52 & 157.50 \\
\hline M10 & 428247.51 & 9222242.73 & 157.40 \\
\hline M11 & 428288.84 & 9222224.72 & 157.97 \\
\hline M12 & 428330.06 & 9222206.75 & 157.47 \\
\hline M13 & 428252.71 & 9222254.66 & 150.02 \\
\hline M14 & 428293.99 & 9222236.84 & 149.98 \\
\hline M15 & 428335.16 & 9222218.95 & 150.04 \\
\hline M16 & 428259.88 & 9222271.34 & 140.12 \\
\hline M17 & 428301.14 & 9222253.56 & 140.02 \\
\hline M18 & 428342.45 & 9222235.64 & 140.25 \\
\hline M19 & 428308.17 & 9222269.97 & 129.89 \\
\hline M20 & 428315.34 & 9222286.53 & 119.90 \\
\hline M21 & 428322.29 & 9222302.50 & 110.10 \\
\hline
\end{tabular}

Tabel 3 Posisi patok geser kondisi selesai pengisian awal

\begin{tabular}{cccc}
\hline Patok & $\mathrm{X}$ & $\mathrm{Y}$ & $\mathrm{Z}$ \\
\cline { 1 - 1 } $\mathrm{M} 1$ & Tidak ada data & Tidak ada data & $\begin{array}{c}\text { Tidak ada } \\
\text { data }\end{array}$ \\
\cline { 1 - 1 } M2 & & 9222217.20 & 150.19 \\
\cline { 1 - 3 } M3 & 428236.60 & 9 & \\
\hline
\end{tabular}




\begin{tabular}{llll}
\hline M5 & 428277.79 & 9222199.39 & 150.05 \\
\hline M6 & 428319.08 & 9222181.60 & 150.08 \\
\hline M7 & 428243.96 & 9222234.38 & 157.27 \\
\hline M8 & 428285.22 & 9222216.60 & 157.78 \\
\hline M9 & 428326.48 & 9222198.57 & 157.36 \\
\hline M10 & 428247.58 & 9222242.76 & 157.26 \\
\hline M11 & 428288.86 & 9222224.78 & 157.77 \\
\hline M12 & 428330.04 & 9222206.80 & 157.32 \\
\hline M13 & 428252.76 & 9222254.71 & 149.91 \\
\hline M14 & 428294.01 & 9222236.91 & 149.83 \\
\hline M15 & 428335.16 & 9222219.01 & 149.93 \\
\hline M16 & 428259.93 & 9222271.38 & 140.03 \\
\hline M17 & 428301.18 & 9222253.63 & 139.88 \\
\hline M18 & 428342.46 & 9222235.69 & 140.21 \\
\hline M19 & 428308.19 & 9222270.02 & 129.79 \\
\hline M20 & 428315.32 & 9222286.55 & 119.82 \\
\hline M21 & 428322.25 & 9222302.54 & 110.04 \\
\hline
\end{tabular}

\subsection{Klasifikasi Bendungan Jatibarang}

Klasifikasi Bendungan Jatibarang berdasarkan zonasi timbunan pada bendungan, ketebalan inti core, dan metode pemadatannya (Foster, 1999), merupakan bendungan dengan tipe urugan batu zona inti tengah. mempunyai 2 (dua) zona filter di zona semi pervious hilir tubuh bendungan sedangkan pada bagian pondasi tidak terdapat filter, mempunyai klasifikasi inti core tipis dengan 33,25 meter pada tinggi bendungan di atas pondasi terdalam $74 \mathrm{~m}$, kemiringan hulu 1:2,6 kemiringan hilir 1:1,8. Berdasarkan metode pelaksanaan bahwa penimbunan dan pemadatan termasuk klasifikasi well compacted dengan tipe core merupakan clay (CL) (BBWS Pemali Juana, 2009). Klasififikasi ditunjukkan pada Tabel 4.

Tabel 4 Klasifikasi Bendungan Jatibarang

\begin{tabular}{cccccc}
\hline \multirow{2}{*}{ Bendungan } & Tinggi & \multicolumn{4}{c}{ Klasifikasi Embankment } \\
\cline { 3 - 6 } & $(\mathrm{m})$ & Zone Clasification & Ukuran Core & Tipe Core & Tipe Pemadatan \\
\hline Jatibarang & 74 & $5,2,0$ & c-tn & CL & Well compacted \\
\hline
\end{tabular}

\subsection{Kriteria Penerimaan Deformasi}

Perilaku deformasi didasarkan pada kriteria penerimaan kurva historis deformasi dari bendungan dengan tipe timbunan yang sama sehingga didapatkan persamaan matematis yang dapat digunakan untuk menentukan nilai batas deformasi yang diizinkan.

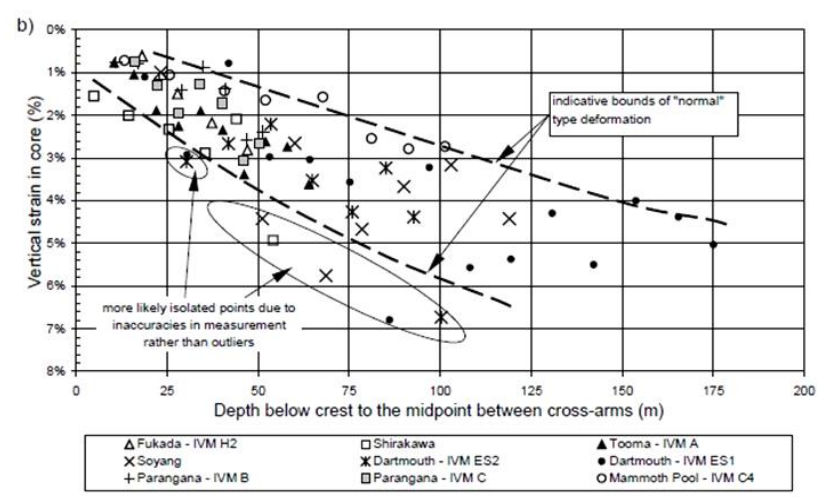

Gambar 4 Kriteria penerimaan deformasi selama konstruksi

Perilaku Deformasi Bendungan Jatibarang - Fajar Aldoko Kurniawan, S.P.R Wardani, Kresno Wikan Sadono 
Hunter, G., \& Fell (2003a) telah melakukan penilaian pada beberapa studi kasus tentang perilaku deformasi pada suatu bendungan pada kondisi normal atau abnormal. Perilaku ini dinilai berdasarkan kumpulan data bendungan lain yang memiliki instrumen. Database yang digunakan sebanyak 134 buah bendungan urugan yang terdiri dari 84 bendungan rockfill, 33 bendungan earthfill, dan 17 puddle earth. Pada Gambar 4 untuk kriteria penerimaan deformasi selama konstruksi, Gambar 5 untuk pengisian awal, sedangkan Tabel 5 untuk penerimaan pasca konstruksi masa layan.

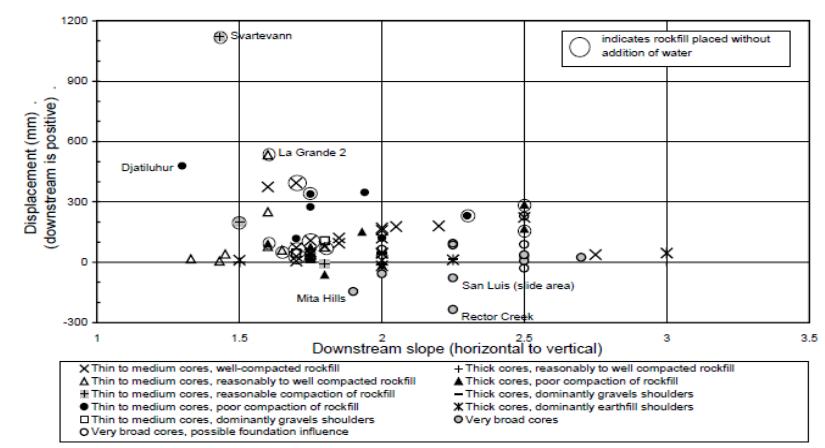

Gambar 5 Kriteria penerimaan deformasi selama pengisian awal

Tabel 5 Kriteria penerimaan batas deformasi (Hunter, G., \& Fell, 2003a)

\begin{tabular}{|c|c|c|c|}
\hline Referensi & Jenis & $\begin{array}{c}\text { Rentang Deformasi } \\
\text { (\% dari tinggi bendungan) }\end{array}$ & Komentar \\
\hline ICOLD (1993) & "Rockfill" & $\begin{array}{l}0,2 \text { hingga } 1,0 \% \\
0,1 \text { hingga } 0,5 \% \\
0,1 \text { hingga } 0,2 \%\end{array}$ & $\begin{array}{l}\text { Perpindahan puncak hingga } \\
50 \% \text { dari penurunan puncak. }\end{array}$ \\
\hline $\begin{array}{l}\text { Sowers et al } \\
\quad(1965)\end{array}$ & "Rockfill" & $\begin{array}{c}0,25 \text { hingga } 1,0 \% \\
\text { (Kisaran atas untuk RF yang dibuang) }\end{array}$ & $\begin{array}{c}14 \text { bendungan, penurunan } \\
\text { hingga } 10 \text { tahun setelah } \\
\text { konstruksi. }\end{array}$ \\
\hline \multirow{2}{*}{$\begin{array}{l}\text { Sherard dkk } \\
\quad(1963)\end{array}$} & "Rockfill" & $\begin{array}{c}0,1 \text { hingga } 0,4 \% \text { (untuk RF yang } \\
\text { dibangun dengan baik) }\end{array}$ & $\begin{array}{l}\text { Penyelesaian yang lebih besar } \\
\text { untuk RF yang dibuang. }\end{array}$ \\
\hline & $\begin{array}{l}\text { Bendungan } \\
\text { yang dibangun } \\
\text { dengan baik }\end{array}$ & $<25$ hingga $50 \mathrm{~mm}$ & $\begin{array}{c}\text { Perpindahan yang lebih besar } \\
\text { untuk bendungan dengan RF } \\
\text { yang dibuang. }\end{array}$ \\
\hline
\end{tabular}

\section{Hasil dan Pembahasan}

\subsection{Deformasi Selama Konstruksi}

Selama konstruksi deformasi yang dominan adalah vertical deformation hal ini dikarenakan adanya proses penimbunan.

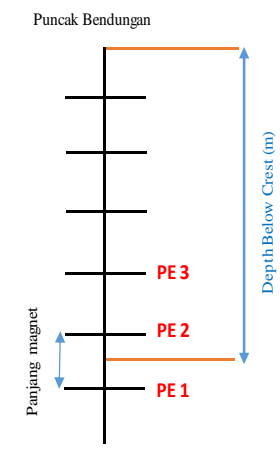

Gambar 6 Ilustrasi perhitungan depth below crest 
Pembacaan deformasi vertikal menggunakan alat probe extenzometer pemasangan awal pada periode konstruksi tanggal 6 Maret 2013 hingga end of construction pada tanggal 6 Mei 2014. Depth below crest dapat diartikan bahwa kedalaman magnet probe extensometer dihitung dari puncak bendungan sampai titik tengah yang berada diantara dua magnet. Ilustrasi perhitungan depth below crest ditunjukkan pada Gambar 6 dan hasil perhitungan ditunjukkan pada Tabel 6.

Tabel 6 Hasil perhitungan depth below crest

\begin{tabular}{cc}
\hline Magnet & $\begin{array}{c}\text { Kedalaman dari Puncak } \\
(\mathbf{m})\end{array}$ \\
\hline PE 1 - PE 2 & 74.98 \\
\hline PE 2 - PE 3 & 70.91 \\
\hline PE 3 - PE 4 & 65.71 \\
\hline PE 4 - PE 5 & 60.96 \\
\hline PE 5 - PE 6 & 56.36 \\
\hline PE 6 - PE 7 & 51.37 \\
\hline PE 7 - PE 8 & 46.67 \\
\hline PE 8 - PE 9 & 41.92 \\
\hline PE 9 - PE 10 & 36.99 \\
\hline PE 10 - PE 11 & 32.09 \\
\hline PE 11 - PE 12 & 26.99 \\
\hline PE 12 - PE 13 & 21.86 \\
\hline PE 13 - PE 14 & 16.71 \\
\hline PE 14 - PE 15 & 11.49
\end{tabular}

Perhitungan vertical strain diperoleh dari menghitung selisih antara perubahan panjang awal antar magnet dengan panjang magnet terakhir pada data pembacaan dibagi dengan panjang maawal. Panjang magnet dihitung dari jarak posisi antar 2 magnet (contoh PE 1 - PE 2) lihat Gambar 6. Sebagai contoh pembacaan initial elevation PE 1 adalah 83.60, sedangkan pembacaan elevasi PE 2 adalah 88.98 maka panjang magnet initial (PE 2 - PE 1) adalah 5.38. Pembacaan elevasi PE 1 adalah 83.50, sedangkan pembacaan elevasi PE 2 adalah 88.69 maka panjang magnet saat end of construction (PE 2 - PE 1) adalah 5.19. Sehingga perubahan panjang sebesar $0.19 \mathrm{~m}$. Vertical strain yang terjadi dihitung pada 0.19/5.38 sehingga didapatkan nilai 0.035 atau 3.5\%. Vertical strain ditampilkan dalam bentuk persentase (\%) ditunjukkan pada Tabel 7.

Tabel 7 Perhitungan vertical strain

\begin{tabular}{ccccc}
\hline Magnet & $\begin{array}{c}\text { Panjang Magnet } \\
\text { Awal }(\mathrm{m})\end{array}$ & $\begin{array}{c}\text { Panjang Magnet } \\
\text { Pembacaan }(\mathrm{m})\end{array}$ & $\begin{array}{c}\text { Perubahan } \\
\text { Panjang }(\mathrm{m})\end{array}$ & Vertical Strain \\
\hline PE 1 - PE 2 & 5.38 & 5.19 & 0.19 & $3.5 \%$ \\
\hline PE 2 - PE 3 & 5.41 & 5.20 & 0.21 & $3.9 \%$ \\
\hline PE 3 - PE 4 & 4.47 & 4.31 & 0.16 & $3.7 \%$ \\
\hline PE 4 - PE 5 & 5.15 & 4.89 & 0.26 & $5.0 \%$ \\
\hline PE 5 - PE 6 & 5.38 & 5.09 & 0.29 & $5.4 \%$ \\
\hline PE 6 - PE 7 & 4.53 & 4.33 & 0.21 & $4.6 \%$ \\
\hline PE 7 - PE 8 & 5.41 & 5.16 & 0.25 & $4.6 \%$ \\
\hline PE 8 - PE 9 & 4.92 & 4.71 & 0.21 & $4.3 \%$ \\
\hline PE 9 - PE 10 & 5.25 & 5.09 & 0.16 & $3.0 \%$ \\
\hline PE 10 - PE 11 & 5.31 & 5.12 & 0.19 & $3.6 \%$ \\
\hline PE 11 - PE 12 & 5.25 & 5.14 & 0.11 & $2.1 \%$ \\
\hline PE 12 - PE 13 & 5.26 & 5.17 & 0.09 & $1.7 \%$ \\
\hline
\end{tabular}

Perilaku Deformasi Bendungan Jatibarang - Fajar Aldoko Kurniawan, S.P.R Wardani, Kresno Wikan Sadono 


\begin{tabular}{ccccc}
\hline Magnet & $\begin{array}{c}\text { Panjang Magnet } \\
\text { Awal }(\mathrm{m})\end{array}$ & $\begin{array}{c}\text { Panjang Magnet } \\
\text { Pembacaan }(\mathrm{m})\end{array}$ & $\begin{array}{c}\text { Perubahan } \\
\text { Panjang }(\mathrm{m})\end{array}$ & Vertical Strain \\
\hline PE 13 - PE 14 & 5.29 & 5.26 & 0.04 & $0.7 \%$ \\
\hline PE 14 - PE 15 & 5.05 & 5.03 & 0.02 & $0.4 \%$ \\
\hline
\end{tabular}

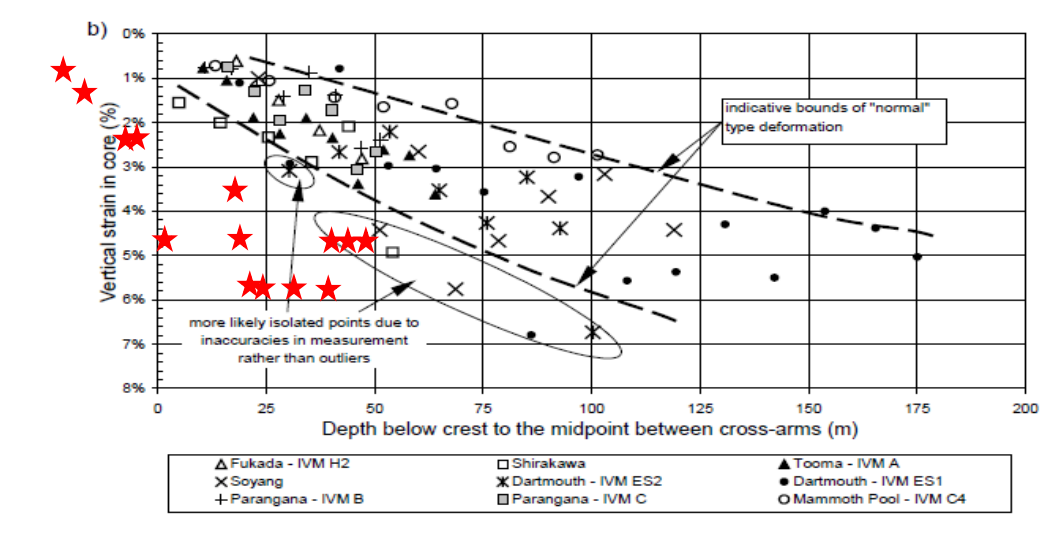

= Bendungan Jatibarang

Gambar 7 Evaluasi deformasi selama konstruksi berdasarkan kriteria penerimaan (Hunter, G., \& Fell, 2003a)

Berdasarkan hasil dari evaluasi deformasi kriteria penerimaan, deformasi vertikal (lihat Gambar 4) pada kedalaman antara $32 \mathrm{~m}$ sampai kedalaman $56 \mathrm{~m}$ berada pada luar batas deformasi normal sehingga terdapat indikasi bahwa pada kedalaman tersebut terjadi ketidaknormalan deformasi. Ketidaknormalan ini dapat terjadi karena adanya efek arching, perubahan susunan dan rongga pada tanah.

\subsection{Deformasi Selama Pengisian Awal}

Pada fase pengisian awal deformasi yang terjadi terkonsentrasi pada hilir bendungan, hal ini dikarenakan adanya beban loading air pada hulu yang mempengaruhi pergerakan (deformasi) horizontal kearah hilir dan abutment bendungan. Analisis deformasi horizontal dilakukan dengan melakukan perhitungan perubahan posisi antara kondisi awal pemasangan pada periode sebelum pengisian awal (6 Mei 2014) dengan kondisi setelah selesai pengisian awal (12 Mei 2015) yang ditunjukkan pada Tabel 2 dan Tabel 3. Pergerakan deformasi horizontal difokuskan pada posisi hilir bendungan di area mid to downstream yaitu pada area $0.6 \mathrm{H}$ (31.44 meter)-0.8 H (58.28 meter) dari puncak bendungan ke hilir.

Pergerakan horizontal yang terjadi pada area mid to downstream ditunjukkan pada pembacaan posisi patok geser M10 - M19 (Tabel 8 dan Tabel 9). Berdasarkan Tabel 10 dapat disimpulkan bahwa pergerakan yang terjadi didominasi oleh pergerakan kearah abutment kiri (barat) dan kearah hilir dari Bendungan Jatibarang.

Tabel 8 Perhitungan pergerakan horizontal Bendungan Jatibarang

\begin{tabular}{ccccc}
\hline Patok Geser & X (initial) & X (pengisian awal) & Selisih (mm) & Pergerakan ke- \\
\hline M10 & 428247.514 & 428247.577 & -63.00 & abutment kiri \\
\hline M11 & 428288.84 & 428288.864 & -24.00 & abutment kiri \\
\hline M12 & 428330.063 & 428330.036 & 27.00 & abutment kanan \\
\hline M13 & 428252.711 & 428252.764 & -53.00 & abutment kiri \\
\hline M14 & 428293.988 & 428294.013 & -25.00 & abutment kiri \\
\hline M15 & 428335.163 & 428335.155 & 8.00 & abutment kanan \\
\hline M16 & 428259.883 & 428259.927 & -44.00 & abutment kiri \\
\hline
\end{tabular}




\begin{tabular}{lcccc}
\hline M17 & 428301.143 & 428301.175 & -32.00 & abutment kiri \\
\hline M18 & 428342.45 & 428342.455 & -5.00 & abutment kiri \\
\hline M19 & 428308.166 & 428308.19 & -24.00 & abutment kiri \\
\hline
\end{tabular}

Tabel 9 Perhitungan pergerakan horizontal (hilir) Bendungan Jatibarang

\begin{tabular}{ccccc}
\hline Patok Geser & Y (initial) & Y (pengisian awal) & Selisih $(\mathrm{mm})$ & Pergerakan ke- \\
\hline M10 & 9222242.73 & 9222242.76 & -31.00 & hilir \\
\hline M11 & 9222224.72 & 9222224.78 & -63.00 & hilir \\
\hline M12 & 9222206.75 & 9222206.80 & -58.00 & hilir \\
\hline M13 & 9222254.66 & 9222254.71 & -42.00 & hilir \\
\hline M14 & 9222236.84 & 9222236.91 & -67.00 & hilir \\
\hline M15 & 9222218.95 & 9222219.01 & -59.00 & hilir \\
\hline M17 & 9222271.34 & 9222271.38 & -47.00 & hilir \\
\hline M18 & 9222253.56 & 9222253.63 & -65.00 & hilir \\
\hline M19 & 9222235.64 & 9222235.69 & -49.00 & hilir
\end{tabular}

Tabel 10 Rekapitulasi pergerakan patok geser pada area Mid to Downstream

\begin{tabular}{ccccc}
\hline Patok Geser & Pergerakan $(\mathrm{mm})$ & Arah & Pergerakan $(\mathrm{mm})$ & Arah \\
\hline M10 & 63.00 & abutment kiri & 31.00 & hilir \\
\hline M11 & 24.00 & abutment kiri & 63.00 & hilir \\
\hline M12 & 27.00 & abutment kanan & 58.00 & hilir \\
\hline M13 & 53.00 & abutment kiri & 42.00 & hilir \\
\hline M14 & 25.00 & abutment kiri & 67.00 & hilir \\
\hline M15 & 8.00 & abutment kanan & 59.00 & hilir \\
\hline M16 & 44.00 & abutment kiri & 47.00 & hilir \\
\hline M17 & 32.00 & abutment kiri & 65.00 & hilir \\
\hline M18 & 5.00 & abutment kiri & 49.00 & hilir \\
\hline M19 & 24.00 & abutment kiri & 46.00 & hilir \\
\hline
\end{tabular}

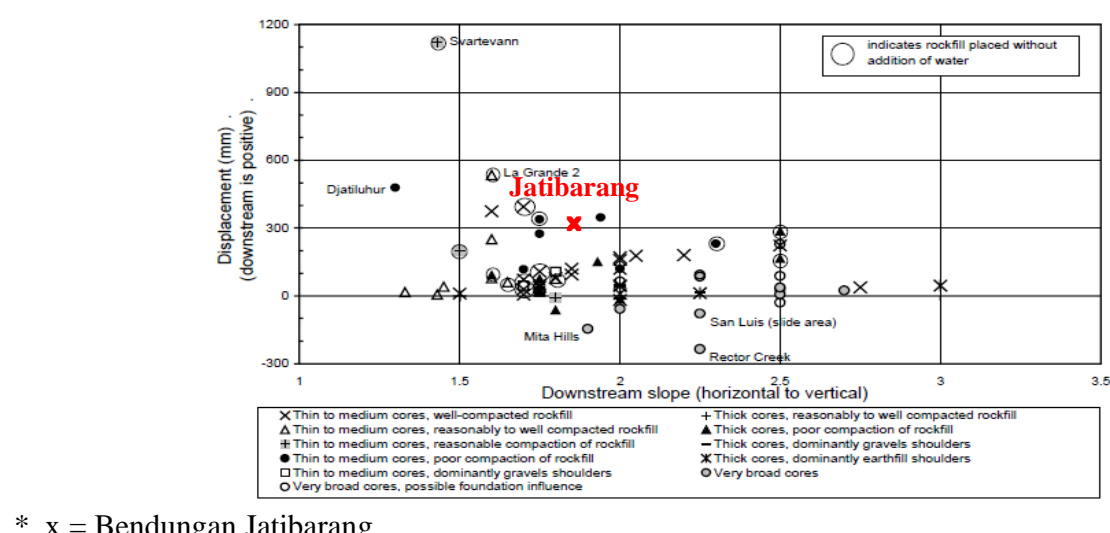

* $\mathrm{x}=$ Bendungan Jatibarang

Gambar 8 Evaluasi deformasi selama pengisian awal berdasarkan kriteria penerimaan (Hunter, G., \& Fell, 2003a)

Evaluasi dan verifikasi dilakukan dengan plotting nilai pergerakan kearah hilir terbesar (patok M14 dengan pergerakan $67 \mathrm{~mm}$ ) di area mid to downstream dengan kemiringan hilir Bendungan Jatibarang sebesar 1:1.8 pada grafik untuk menentukan perilaku deformasi pada pengisian awal (Gambar 8). Pergerakan deformasi horizontal pada pengisian awal dari Bendungan Jatibarang mempunyai nilai deformasi yang besar karena berada di atas perilaku umum deformasi horizontal pada beberapa bendungan. 


\subsection{Deformasi Pasca Konstruksi (Masa Layan)}

Pada pasca konstruksi jangka panjang atau masa layan penurunan yang terjadi merupakan perubahan antara kondisi magnet probe extensometer pada awal pemasangan dengan kondisi pembacaan data terakhir (Tabel 10). Pada kurun waktu konstruksi tahun 2014 hingga pembacaan terakhir pada tahun 2020 (Gambar 9) terlihat tidak terjadi perubahan yang signifikan namun pada kedalaman antara $20-$ 30 meter terjadi penurunan yang besar dibandingkan dengan lainnya yang mengindikasikan bahwa pada kedalaman tersebut terjadi konsentrasi penurunan internal yang besar. Penurunan internal ini diperkirakan akibat adanya rongga tanah akibat perubahan bentuk tanah.

Tabel 11 Penurunan pembacaan pada end of construction

\begin{tabular}{cccccc}
\hline Magnet & $\begin{array}{c}\text { Initial } \\
(\mathrm{m})\end{array}$ & Kedalaman & $\begin{array}{c}\text { Data Reading } \\
(\mathrm{m})\end{array}$ & $\begin{array}{c}\text { Penurunan } \\
(\mathrm{m})\end{array}$ & $\begin{array}{c}\text { Penurunan } \\
(\mathrm{mm})\end{array}$ \\
\hline PE 1 & 83.6 & 73.4 & 83.50 & 0.10 & 101 \\
\hline PE 2 & 88.98 & 68.02 & 88.69 & 0.29 & 290 \\
\hline PE 3 & 94.37 & 62.63 & 93.89 & 0.48 & 481 \\
\hline PE 4 & 98.78 & 58.22 & 98.20 & 0.59 & 585 \\
\hline PE 5 & 103.84 & 53.16 & 103.09 & 0.75 & 753 \\
\hline PE 6 & 109.094 & 47.91 & 108.17 & 0.92 & 922 \\
\hline PE 7 & 113.477 & 43.52 & 112.50 & 0.98 & 979 \\
\hline PE 8 & 118.67 & 38.33 & 117.66 & 1.01 & 1014 \\
\hline PE 9 & 123.445 & 33.56 & 122.36 & 1.08 & 1082 \\
\hline PE 10 & 128.453 & 28.55 & 127.46 & 1.00 & 998 \\
\hline PE 11 & 133.62 & 23.38 & 132.57 & 1.05 & 1047 \\
\hline PE 12 & 138.497 & 18.50 & 137.71 & 0.79 & 788 \\
\hline PE 13 & 143.53 & 13.47 & 142.88 & 0.65 & 649 \\
\hline PE 14 & 148.56 & 8.44 & 148.14 & 0.42 & 424 \\
\hline PE 15 & 153.41 & 3.59 & 153.16 & 0.25 & 248 \\
\hline
\end{tabular}

Tabel 12 Penurunan pembacaan terakhir pada masa layan (post construction)

\begin{tabular}{cccccc}
\hline Magnet & Initial $(\mathrm{m})$ & Kedalaman & $\begin{array}{c}\text { Pembacaan } \\
\text { Data }(\mathrm{m})\end{array}$ & $\begin{array}{c}\text { Penurunan } \\
(\mathrm{m})\end{array}$ & $\begin{array}{c}\text { Penurunan } \\
(\mathrm{mm})\end{array}$ \\
\hline PE 1 & 83.60 & 73.40 & 83.50 & 0.10 & 101 \\
\hline PE 2 & 88.98 & 68.02 & 88.69 & 0.29 & 290 \\
\hline PE 3 & 94.37 & 62.63 & 93.88 & 0.50 & 495 \\
\hline PE 4 & 98.78 & 58.22 & 98.17 & 0.61 & 612 \\
\hline PE 5 & 103.84 & 53.16 & 103.05 & 0.79 & 788 \\
\hline PE 6 & 109.09 & 47.91 & 108.13 & 0.97 & 967 \\
\hline PE 7 & 113.48 & 43.52 & 112.43 & 1.05 & 1049 \\
\hline PE 8 & 118.67 & 38.33 & 117.57 & 1.10 & 1102 \\
\hline PE 9 & 123.45 & 33.56 & 122.27 & 1.18 & 1179 \\
\hline PE 10 & 128.45 & 28.55 & 127.36 & 1.09 & 1095 \\
\hline PE 11 & 133.62 & 23.38 & 132.47 & 1.15 & 1146 \\
\hline PE 12 & 138.50 & 18.50 & 137.61 & 0.89 & 891 \\
\hline PE 13 & 143.53 & 13.47 & 142.76 & 0.77 & 766 \\
\hline PE 14 & 148.56 & 8.44 & 148.00 & 0.56 & 565 \\
\hline PE 15 & 153.41 & 3.59 & 153.03 & 0.38 & 383 \\
\hline
\end{tabular}

Berdasarkan hasil perhitungan pada Tabel 11 bahwa nilai deformasi pada end of construction yang terbesar adalah $1.08 \mathrm{~m}$ dan pada Tabel 12 masa layan sebesar $1.18 \mathrm{~m}$ sehingga pada rentang selesainya konstruksi Bendungan Jatibarang sampai terakhir masa layan terjadi deformasi maksimal sebesar $0.1 \mathrm{~m}$ dengan tinggi 
Bendungan Jatibarang adalah $74 \mathrm{~m}$ (deformasi sebesar $0.13 \%$ dari tinggi bendungan) maka dapat disimpulkan bahwa pada saat setelah konstruksi hingga 5 tahun saat ini deformasi di Bendungan Jatibarang masih aman dengan kriteria tidak melebihi batas penerimaan deformasi (Tabel 13).

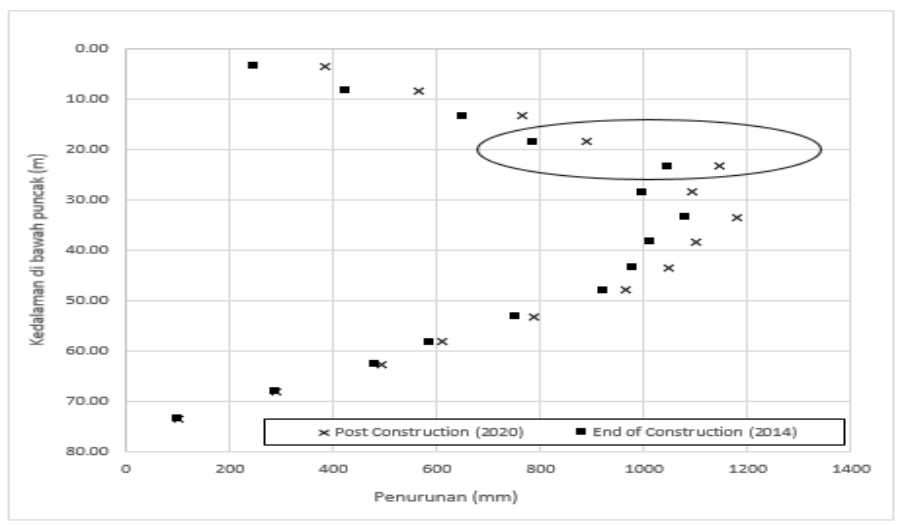

Gambar 9 Perbandingan nilai deformasi Bendungan Jatibarang End of Construction dan Post Construction (masa layan)

Tabel 13 Kriteria penerimaan pasca konstruksi (masa layan)

\begin{tabular}{cccc}
\hline Referensi & $\begin{array}{c}\text { Kriteria (\% dari } \\
\text { Tinggi Bendungan) }\end{array}$ & $\begin{array}{c}\text { Bendungan } \\
\text { Jatibarang }\end{array}$ & Keterangan \\
\hline ICOLD (1993) & 0.2 hingga 1,0\% & $0.13 \%$ & dibawah kriteria \\
\hline Sowers (1965) & 0,25 hingga 1,0\% & $0.13 \%$ & dibawah kriteria \\
\hline Sherard (1963) & 0,1 hingga $0,4 \%$ & $0.13 \%$ & rentang kriteria \\
\hline
\end{tabular}

\section{Kesimpulan dan Saran}

\subsection{Kesimpulan}

Deformasi vertikal pada kedalaman di antara $32 \mathrm{~m}$ sampai kedalaman $56 \mathrm{~m}$ berada pada luar batas deformasi normal sehingga terdapat indikasi bahwa pada kedalaman tersebut terjadi ketidaknormalan deformasi. Pergerakan deformasi horizontal pada pengisian awal mempunyai nilai deformasi yang besar karena berada di atas perilaku umum deformasi horizontal pada beberapa bendungan. Pada kurun waktu konstruksi tahun 2014 hingga pembacaan terakhir pada tahun 2020 pada kedalaman antara 20-30 meter terjadi penurunan yang besar dibandingkan dengan lainnya yang mengindikasikan bahwa pada kedalaman tersebut terjadi konsentrasi penurunan internal yang besar. Berdasarkan kriteria penerimaan deformasi di Bendungan Jatibarang masih aman dengan kriteria tidak melebihi batas penerimaan deformasi. Hal ini dapat dikarenakan pada klasifikasi Bendungan Jatibarang termasuk dalam klasifikasi well compacted dengan inti core clay.

\subsection{Saran}

Meningkatkan kualitas data monitoring dengan melakukan pencatatan instrumentasi secara tertib dan berkala khususnya yang berhubungan dengan pengukur deformasi untuk menilai perilaku bendungan serta melakukan rekapitulasi dan perbandingan dengan tinjauan lapangan, evaluasi pembacaan instrumentasi serta pemodelan numerik dan atau pemodelan fisik untuk memberikan gambaran tentang perilaku bendungan secara lengkap dan mendalam. 


\section{Daftar Kepustakaan}

BBWS Pemali Juana, 2009. Laporan Pembangunan Bendungan Jatibarang. Semarang.

BBWS Pemali Juana, 2010. Multipurpose Dam Jatibarang "Instumentation for Dam Safety Monitoring. Semarang.

BBWS Pemali Juana, 2014. Pedoman Operasi dan Pemeliharaan Bendungan Jatibarang. Semarang.

BBWS Pemali Juana, 2020. Pemantauan Instrumentasi Bendungan Jatibarang. Semarang. Semarang.

Bureau of Reclamation, 2012. Design Standar No.13 Embankment Dams. U.S: Department of Interior Bureau of Reclamation.

Fajar Rudi Purwoko, 2016. Pemantauan Deformasi Bendungan Jatibarang Menggunakan Scientific Software Gamit 10.6 Dengan Titik Ikat IGS Dan CORS CSEM. Universitas Diponegoro.

Foster, M, 1999. The Probability of Failure Of Embankment Dams by Internal Erosion and Piping. The University of New South Wales.

Hunter, G., \& Fell, R. (no date a). The Deformation Behaviour of Embankment Dams. Sydney: University of New South Wales.

Hunter, G., \& Fell, R. (no date b). The University Of Embankment Dams, (Februari). Sydney.

ICOLD. 1993. The Constitutional.

Kementerian Pekerjaan Umum dan Perumahan Rakyat, 2008. Integrated Water Resources And Flood Management Project For Semarang (Jbic Loan Ip-534). Design Review Report Jatibarang Multipurpose Dam.

M. Adnan Yusuf, 2015. Pengamatan GPS Untuk Monitoring Deformasi Bendungan UNDIP. Universitas Diponegoro.

Rheky Julistian, 2020. Analisis Kestabilan Bendungan Lolak 1. Universitas Sam Ratulangi.

Rizki Fadillah, Bambang Darmo Yuwono, B. S, 2017. Studi Deformasi Waduk Pendidikan Diponegoro Tahun 2016. Jurnal Geodesi UNDIP.

Sherard, J.L., R.J. Woodward, S.F. Gizienski, and W. A. C, 1963. Earth and Earth Rock Dams. Edited by John Wiley and Sons. New York.

Sowers, G.F., Davie, J., Soenarno and Mansoer, M, 1965. Compressibility of Broken Rock and The Settlement of Rockfills. Montreal: University of Toronto.

TADS (Training Aids for Dam Safety), 2011. Evaluation of Embankment Dam Stability and Deformation.

USBR, 2011. Embankment Dams.

Copyright (c) Fajar Aldoko Kurniawan, S.P.R Wardani, Kresno Wikan Sadono

Perilaku Deformasi Bendungan Jatibarang - Fajar Aldoko Kurniawan, S.P.R Wardani, Kresno Wikan Sadono 